\title{
SISTEM PERTAHANAN DI MALUKU ABAD XVII-XIX (Kajian Terhadap Pola Sebaran Benteng)
}

\author{
Syahruddin Mansyur
}

........ Oleh karena itu pula bukan suatu kebetulan bahwa banyak rempah-rempah disebut sebagai 'aphrodisiac', zat perangsang nafsu birahi. Kemudian bila dihubungkan dengan masa lampau dan kepulauan yang mengagumkan, maka rempah-rempah ternyata ikut mewarnai berbagai jenis kesusastraan, yang telah mempermudah pencapaian kenikmatan penuh sensasi sekaligus kemisteriusan dunia Timur (Mulherin, 1994 dalam Kustoro dan Rumere, 2004).

\section{Pengantar}

Daya tarik rempah-rempah yang dihasilkan oleh dunia Timur itulah yang kemudian mengundang kedatangan bangsa Eropa ke nusantara untuk memperoleh rempah-rempah langsung dari tangan pertama. Hasrat ini kemudian telah mempengaruhi hubungan internasional antar bangsa dan menjadi faktor utama perjalanan sejarah dunia sekitar abad XV hingga XX. Berlangsungnya kolonisasi di negara Asia dan Afrika yang dulunya terdiri dari kerajaan-kerajaan lokal menjadi salah satu buktinya. Dengan tujuan awal ekonomi, orang-orang Eropa hanya menempatkan wakil perdagangannya di wilayah-wilayah penghasil komoditi yang dibutuhkan. Akan tetapi, melihat keuntungan yang diperoleh dalam perdagangan rempahrempah yang besar maka penguasaan atas wilayah penghasil komoditi tersebut menjadi keharusan. Hal inilah yang menjadi faktor utama pembangunan benteng-benteng pertahanan di wilayah-wilayah yang dianggap penting.

Tulisan ini mencoba melakukan kajian terhadap bentengbenteng pertahanan yang dibangun oleh bangsa Kolonial khususnya Belanda. Kajian ini untuk mengetahui sistem pertahanan yang dibangun dalam rangka menguasai perdagangan rempah-rempah di Maluku (Propinsi Maluku dan Propinsi Maluku Utara). 


\section{Pendahuluan}

Tujuan utama pendirian sebuah benteng dimaksudkan untuk melindungi diri dari gangguan-gangguan yang datang dari luar. Di Indonesia, benteng sudah dikenal sejak jaman prasejarah. Pada masa itu benteng dibangun dengan cara membuat gundukan tanah yang melingkar untuk melindungi suatu pemukiman atau suatu tempat yang dianggap, penting (Triwuryani 1995). Benteng-benteng pertahanan seperti ini sering dijumpai pada permukiman-permukiman kuno. Di Maluku sendiri, bentuk pertahanan kelompok seperti ini banyak dijumpai di pemukiman-pemukiman lama yang terdiri dari susunan batu dan dikenal dengan "negeri lama".

Di Indonesia, teknologi pembangunan benteng yang lebih kuat dapat dilihat pada benteng yang dibangun oleh bangsa Eropa khususnya Portugis. Teknologi yang digunakan yaitu dengan menggunakan bahan batu bata dan batu alam serta penggunaan spesi campuran pasir dan kapur karang. Demikianlah maka, benteng-benteng yang saat ini berdiri dengan kokoh dulunya dibangun oleh orang-orang Eropa.

Pembangunan benteng-benteng tersebutlah yang kemudian menjadi faktor pendukung keberhasilan bangsa kolonial menguasai nusantara. Dengan menerapkan strategi dan sistem pertahanan pada awal pendudukannya di setiap daerah yang mereka anggap penting atau menguntungkan maka penguasaan tersebut dapat berlangsung selama berabad-abad. Abbas (2005), menyebutkan bahwa faktor-faktor yang melatari pemilihan lokasi pendirian sebuah benteng diantaranya:

1. Pentingnya suatu daerah pada masa pendirian benteng (misalnya potensi tempat itu untuk dijadikan pusat perdagangan, adanya suplai produksi yang dibutuhkan, dan potensi untuk digunakan sebagai pusat pemerintahan lokal).

2. Ancaman atau penolakan yang dihadapi (misalnya ancaman eksternal dari orang-orang asing atau ancaman internal dari penguasa setempat).

3. Strategi yang diterapkan dalam upayanya menaklukkan suatu wilayah tertentu untuk perluasan kekuasaan.
Khusus untuk wilayah Maluku, daerah-daerah yang dianggap penting pada saat itu diantaranya, Kepulauan Banda, Kepulauan Ambon (dan pulau-pulau Lease) serta Maluku Utara (Moluco Kie Raha). Daerah-daerah ini dianggap penting karena merupakan daerah pengumpul dalam perdagangan rempah-rempah sebelum dibawa ke pedagang-pedagang Internasional di Malaka atau langsung ke Eropa.

Tulisan ini akan melakukan kajian terhadap sistem pertahanan di Maluku abad XVII hingga XIX. Untuk itu, dilakukan pengamatan terhadap benteng-benteng yang dibangun oleh bangsa Eropa khususnya Belanda dalam usaha memonopoli perdagangan rempah-rempah di Maluku. Selain itu, fokus terhadap Belanda (termasuk VOC) dalam hal ini tidak lain dimaksudkan karena dalam perebutan diantara negaranegara Eropa yang menginginkan penguasaan terhadap wilayah ini, dianggap yang berhasil. Sementara itu kurun waktu selama abad XVII hingga abad XIX merupakan perjalanan waktu yang cukup panjang dalam usaha tersebut. Dalam kurun waktu tersebutlah bangsa Eropa membangun benteng-benteng pertahanan di Maluku.

Dengan demikian, sistem pertahanan di Maluku pada abad XVII hingga XIX, perlu dikaji sebagai usaha pemahaman terhadap sejarah tidak hanya sejarah Maluku tetapi juga sejarah bangsa Indonesia. Selama kurun waktu tersebut perebutan wilayah penghasil rempahrempah terbesar di dunia tidak hanya melibatkan pedagang nusantara dan pedagang-pedagang Eropa tetapi juga pedagang dari negara lain seperti Cina dan Arab.

\section{Latar Sejarah}

Untuk dapat memahami sistem pertahanan Belanda maka perlu diketahui sejarah serta apa kepentingan Belanda yang melatari pembangunan sistem pertahanan tersebut. Seperti telah diketahui bahwa kepentingan utama bangsa Kolonial datang ke wilayah ini diawali oleh kepentingan ekonomi. Di dataran Eropa pada saat itu perdagangan rempah-rempah sangat ramai dan banyak diminati oleh orang-orang Eropa yang digunakan sebagai bahan untuk menambah rasa masakan dan sebagai bahan untuk membuat wewangian. Keuntungan 
yang diperoleh melalui perdagangan rempah-rempah sangatlah besar karena setiap berpindah tangan keuntungan yang diperoleh mencapai 100\% sehingga setibanya di Eropa dapat mencapai seribu persen (Hanna, 1983:2). Demikianlah, maka negara-negara Eropa kemudian berlomba-lomba "menjemput emas" (dengan mendatangi sentra produksi rempah-rempah di dunia timur) untuk mendapat keuntungan yang berlipat.

Pada awalnya, rempah-rempah diperkenalkan oleh pedagangpedagang Cina dan Arab ke Eropa. Berbagai kegiatan arkeologis dan catatan sejarah menyebutkan bahwa pedagang-pedagang nusantara telah melibatkan diri dalam perdagangan internasional. Rute perdagangan dari Cina melalui kepulauan Nusantara ke India, Persia dan Mesir, Eropa dan sebaliknya. Berbagai komoditas yang dibawa ke India dimana telah menunggu saudagar-saudagar Asia Barat (orang Persia dan Arab, mula-mula juga orang Yunani dan Mesir) yang akan membawa ke pasaran Eropa (Kustoro dan Rumere, 2004).

Maluku sendiri menjadi salah satu wilayah penting dalam perdagangan internasional sejak jaman lampau, dimana wilayah ini telah disinggahi oleh kapal-kapal dagang dari kerajaan Sriwijaya, kemudian kerajaan Majapahit, dan terus berlanjut pada masa Islam dan masa kedatangan bangsa Eropa (Suantika, 2005). Bahkan jauh sebelumnya, sumber-sumber Cina menyebutkan bahwa perdagangan rempah-rempah telah melibatkan pedagang-pedagang Nusantara yang berlayar antara Cina dan India sekitar abad ke-5 dan ke-6 (Selling, 1981 dalam Kustoro dan Rumere, 2004). Kemudian mulai abad ke-7, secara teratur pedagang Arab yang kebanyakan datang dari India berlayar ke Asia Tenggara. Perdagangan secara meluas tidak saja dilakukan di Nusantara bahkan mencapai belahan selatan Cina (Hall, 1968 dalam Ibid). Dan pada abad-abad selanjutnya pedagang-pedagang Arab kemudian datang dengan membawa dan menyebarkan agama Islam di Nusantara.
Tergiur dengan keuntungan besar yang diperoleh dari perdagangan rempah-rempah dan semangat petualangan untuk menjelajahi dunia, bangsa Eropa kemudian datang ke Nusantara.

Sejarah kedatangan orang-orang Eropa ke wilayah ini diawali oleh bangsa Portugis. Portugis pada abad ke-16 berhasil menguasai Malaka sebagai salah satu pusat perdagangan rempah-rempah yang kemudian berhasrat untuk mendatangi sentra produksi rempahrempah di Maluku. Setelah keberhasilan pertama tersebut Portugis kemudian mencapai keberhasilan berikutnya yaitu menguasai sentra produksi rempah-rempah dengan melakukan kerjasama perdagangan dengan Ternate. Pada awalnya, daerah pertama yang mereka datangi adalah Kepulauan Banda akan tetapi kemudian ditinggalkan dan menuju ke utara yaitu Ternate karena dianggap sebagai Kerajaan yang berpengaruh dan menguasai wilayah Maluku.

Pada masa selanjutnya, negara-negara Eropa yang lain diantaranya Spanyol, Belanda, dan Inggris datang dengan tujuan yang sama. Kedatangan bangsa Eropa ini, pada akhirnya menimbulkan persaingan perdagangan yang ketat, sehingga tejadi perselisihan bahkan peperangan di antara mereka, dan kemudian mereka berusaha mencari/mendapatkan dukungan dari para penguasa wilayah setempat (Sultan, Raja, Tetua desa dan lainnya). Tidak hanya itu, persekutuanpersekutuan dengan penguasa lokal menyebabkan perselisihan dan juga peperangan antara penduduk Maluku itu sendiri (Suantika, 2005). Melihat perselisihan diantara penguasa lokal, kemudian dimanfaatkan oleh Belanda untuk menguasai wilayah ini dengan menerapkan politik pecah belah.

Perebutan diantara negara-negara Eropa atas wilayah ini berlangsung cukup lama. Salah satu wilayah yang dianggap penting pada masa itu adalah Kepulauan Banda. Perebutan atas Banda Neira berlangsung cukup lama dimulai pada awal abad XVI sejak kedatangan bangsa Portugis hingga awal abad XIX yang ditandai dengan pendudukan tentara Inggris atas Benteng Belgica pada tahun 1810. Akan tetapi, dengan adanya perubahan politik di Eropa tentang perjanjian pembagian daerah jajahan maka Banda Neira berada kembali 
dibawa kendali pemerintah Belanda yang ditandai dengan kedatangan Gubernur Jenderal Belanda bernama Baron van der Capellen pada tahun 1824 (Hanna, 1983).

Selain persaingan diantara negara kolonial yang menyebabkan peperangan di Maluku, peperangan juga berlangsung dengan adanya perjuangan rakyat Maluku melawan bangsa Portugis dan Belanda, yaitu :

1. Perang masyarakat Hitu melawan Portugis pada tahun 1538

2. Perang masyarakat Ternate dibawah Pimpinan Sultan Baabullah melawan Portugis pada tahun 1574

3. Perang masyarakat Hitu melawan Belanda yaitu perang Wawane 1634-1643 dan perang Kapahaha pada tahun 16431646

4. Perang Hoamoal pada tahun $1625-1655$

5. Perang Patimura melawan Belanda pada tahun 1817 ( Rijoly, 1989).

Peristiwa penting lainnya yang melatari berbagai perubahanperubahan dalam pendudukan Belanda (VOC) di nusantara umumnya termasuk di Maluku adalah munculnya sentra produksi rempah-rempah di Mauritius pada tahun 1776, dan pada tahun 1799 VOC bangkrut (Koestoro dan Rumere, 2004:61). Dan kekuasaan VOC diambil alih oleh Pemerintah Belanda yang kemudian mengembangkan komoditi lain di Maluku. Selain munculnya sentra produksi rempah-rempah di tempat lain, berbagai hal yang terjadi dalam tubuh VOC menyebabkan kebangkrutan tersebut. Korupsi diantara para pejabat VOC dan laporan berbagai pihak kepada pemerintah Belanda tentang perlakuan petinggi VOC menjadi pertimbangan utama pemerintah Belanda untuk segera mengambil alih penguasaan atas wilayah nusantara.

\section{Pola Sebaran Benteng di Maluku}

Berdasarkan hasil penelitian yang telah dilakukan, terdapat sedikitnya 41 benteng pertahanan yang dibangun oleh bangsa Eropa di Maluku. Banteng-benteng pertahanan tersebut hingga saat ini masih ada dan berdiri kokoh, beberapa diantaranya tinggal pondasi saja akibat berbagai peristiwa yang dialaminya. Dengan tujuan menumbuhkan rasa persatuan dan kesatuan, tinggalan budaya ini telah dilestarikan.

\section{Tabel 1: Sebaran benteng yang ada di Maluku}

\begin{tabular}{|c|c|c|c|c|c|}
\hline \multirow{2}{*}{ No } & \multirow{2}{*}{$\begin{array}{l}\text { NAMA BENTENG } \\
\text { Propinsi Maluku }\end{array}$} & \multicolumn{2}{|c|}{ Lokasi } & \multirow{2}{*}{$\begin{array}{l}\text { Bangsa } \\
\text { pendiri }\end{array}$} & \multirow{2}{*}{$\begin{array}{c}\text { Tahun } \\
\text { Didirikan }\end{array}$} \\
\hline & & Desa/kota & Kecamatan & & \\
\hline 1 & Benteng Nieuw (Warwijk) & Ambon & Sirimau & Belanda & 1599 \\
\hline 2 & Danek Of De Morgenter & Passo & Baguala & Belanda & 1626 \\
\hline 3 & Benteng Roterdam & Larike & Leihitu & Belanda & 1633 \\
\hline 4 & Benteng Wawane & Hila & $\begin{array}{l}\text { Leihitu } \\
\end{array}$ & Belanda & \\
\hline & Benteng Kapahaha & Morela & Leihitu & & \\
\hline 6 & Benteng Blokhuis Harlem & Asilulu & Leihitu & Belanda & 1655 \\
\hline 7 & Benteng V.D. Capellen & Laha & Baguala & Belanda & 1680 \\
\hline 8 & Benteng Duurstede & K. Saparua & Saparua & Belanda & $1690 / 1691$ \\
\hline 9 & Benteng Hollandia & Sirisori & Saparua & Belanda & 1691 \\
\hline 10 & Benteng Beverwyk & Sila & Nusalaut & Belanda & 1845 \\
\hline 11 & Benteng Ama Ika & Iha & $\begin{array}{l}\text { Saparua } \\
\end{array}$ & & \\
\hline 12 & Benteng Ouw & Ouw & Saparua & Belanda & \\
\hline 13 & Benteng Nassau & P. Neira & Bandaneira & Belanda & 1609 \\
\hline 14 & Benteng Belgica & P. Neira & Bandaneira & Belanda & 1611 \\
\hline 15 & Kastel Reveangie & P. Ay & Bandaneira & Belanda & 1616 \\
\hline 16 & Benteng Hollandia & P.Lontor & Bandaneira & Belanda & 1624 \\
\hline 17 & Fort Nieuw Zeelandia & Haruku & P. Haruku & Belanda & 1626 \\
\hline 18 & Benteng Oma & Oma & P. Haruku & Belanda & 1627 \\
\hline 19 & Fort Hoorn & Pelauw & P. Haruku & Belanda & 1656 \\
\hline 20 & Fort Wantrow & Kelang & Seram Barat & & 1657 \\
\hline 21 & Benteng Hardewyk & Amahai & Amahai & Belanda & $1628-1631$ \\
\hline 22 & Benteng Defensie & Kaiyeli & Buru Utara & & 1689 \\
\hline 23 & Fort Delen Haven & Wonreli & P. Kisar & Belanda & 1665 \\
\hline 24 & Benteng Folen Haven & K. Serwaru & Moa & Belanda & 1712 \\
\hline 25 & Benteng Kota Lama & Wokam & P. Aru & Portugis & 1500 \\
\hline 26 & Benteng Den Haan & Patti & Serwaru & Belanda & 1734 \\
\hline & Propinsi Maluku Utara & & & & \\
\hline 1 & Benteng Tolucco & Ternate & Ternate Selatan & Portugis & 1512 \\
\hline 2 & Benteng Santo Pedro'E Paulo & Ternate & Laguna & Portugis & 1532 \\
\hline 3 & Benteng Kalamata & Ternate & Kayu Merah & Portugis & 1640 \\
\hline 4 & Kota Moti & Kota Mati & Makian & - & 1609 \\
\hline 5 & Mouritius & Ngofakiaha & Makian & - & 1613 \\
\hline 6 & Benteng Bernaveld & Labuha & Bacan & & \\
\hline 7 & Kastel Jailolo & Jailolo & Jailolo & - & 1611 \\
\hline 8 & Benteng Moro & Gamlamo & Jailolo & - & ( \\
\hline 9 & Benteng Patu & Laluin & Kayoa & - & - \\
\hline 10 & Benteng Tsjobbe & Tidore & Tidore & - & - \\
\hline 11 & Benteng Tehoela & Rum & Rum & - & - \\
\hline & Benteng Fatkota & Malbufa & Sanana & Portugis & - \\
\hline 13 & Fort Sabopgo & Sahu & Sahu & Spanyol & \\
\hline 14 & Benteng Orange & Ternate & Ternate & Belanda & 1607 \\
\hline 15 & Benteng Deverwakting & Mangon & Sanana & Belanda & 1662 \\
\hline
\end{tabular}


Berdasarkan tabel diatas, sebaran benteng yang ada di propinsi Maluku sebanyak 26 benteng, sementara di propinsi Maluku Utara sebanyak 15 benteng. Benteng yang ada di Maluku sebagian besar dibangun oleh Belanda dan Inggris, sementara di Maluku Utara dibangun oleh Portugis dan Spanyol. Beberapa diantara bentengbenteng tersebut dibangun dan difungsikan kembali oleh Belanda setelah ditinggalkan oleh Portugis.

Berdasarkan tahun pendiriannya dapat dikelompokkan dalam dua periode yaitu periode Portugis dan periode Belanda. Bentengbenteng Portugis sebagian besar dibangun pada awal abad ke-16 hingga akhir abad ke-16, sementara Belanda dimulai pada akhir abad ke-16 hingga abad ke-19. Berdasarkan data diatas, diketahui bahwa benteng pertama dibangun oleh Portugis yaitu benteng Kota Lama di Wokam Pulau Aru, Maluku Tenggara sekitar tahun 1500. Sementara Belanda mulai membangun benteng Nieuw (Warwijk) pada tahun 1599 di Keitetu pulau Ambon.

Benteng-benteng Portugis yang ada di Maluku Utara paling banyak berada di Ternate (3), dan di daerah lain berada di Pulau Sulabesi (1). Benteng-benteng lain yang diperkirakan dibangun oleh Portugis diantaranya berada di Jailolo dan Bacan (masing-masing 1), setelah benteng ini ditinggalkan barulah diambil alih oleh Belanda diantaranya Kastel Jailolo dan Benteng Bernaveld.

Sedang benteng yang dibangun oleh Belanda paling banyak berada di Pulau Ambon (7), Pulau Saparua (5), Banda (4), dan Pulau Haruku (3), benteng-benteng lainnya tersebar di pulau-pulau lain di Propinsi Maluku. Satu-satunya benteng yang dibangun di Ternate adalah benteng Orange pada tahun 1607.

Sebaran benteng yang dibangun oleh Portugis sekitar abad ke16 hingga 17 di wilayah Maluku yang sebagian besar berada di Maluku Utara berjumlah 13 benteng, beberapa diantara benteng tersebut tidak memiliki data yang lengkap. Benteng-benteng tersebut dimasukkan sebagai kategori yang dibangun oleh Portugis karena pada masa ini Portugis menguasai daerah ini.

Tabel 2: Sebaran benteng yang dibangun oleh Portugis

Tabel 2: Sebaran benteng yang dibangun oleh Portugis
\begin{tabular}{|c|l|l|c|}
\hline No. & \multicolumn{1}{|c|}{ Nama benteng } & \multicolumn{1}{|c|}{ Lokasi } & Tahun \\
\hline 1 & Kota Lama & P. Aru & 1500 \\
\hline 2 & Tolucco of Hollandia & Ternate & 1512 \\
\hline 3 & Santo Pedro'E Paulo & Ternate & 1532 \\
\hline 4 & Kalamata & Ternate & 1640 \\
\hline 5 & Kota Moti & Makian & 1609 \\
\hline 6 & Kastel Jailolo & Jailolo & 1611 \\
\hline 7 & Mouritius & Makian & 1613 \\
\hline 8 & Bernaveld & Bacan & - \\
\hline 9 & Moro & Jailolo & - \\
\hline 10 & Patu & Kayoa & - \\
\hline 11 & Tsjobbe & Tidore & - \\
\hline 12 & Tehoela & Rum & - \\
\hline 13 & Fatkota & Sanana & - \\
\hline
\end{tabular}

Sedang, sebaran benteng di Maluku dan Maluku Utara yang dibangun oleh Belanda berdasarkan tahun pembangunannya dapat dikelompokkan dalam tiga fase yaitu fase I (abad XVI), fase II (abad XVII), dan fase III (abad XVIII-XIX). Data berikut ini merupakan data yang dihimpun dariberbagai sumber, beberapabenteng diantaranyatidak diketahui datanya secara pasti olehnya itu dilakukan perkiraan dengan berbagai pertimbangan tentang negara dan tahun pembangunannya. Diantaranya benteng Wawane dan Kapahaha diperkirakan dibangun sekitar abad ke-17. Pertimbangannya bahwa perang antara masyarakat Hitu dengan Belanda berlangsung pada masa tersebut, dan tentunya benteng ini dibangun pada masa sebelumnya. Sementara itu, bentengbenteng yang tidak diketahui siapa yang membangun dimasukkan sebagai benteng yang dibangun oleh Belanda karena sebagian besar 
berada di wilayah Ambon dan sekitarnya. Lebih lengkap dapat dilihat pada tabel berikut:

Tabel 3: Sebaran benteng yang dibangun pada fase I

\begin{tabular}{|c|l|l|c|}
\hline No. & \multicolumn{1}{|c|}{ Nama benteng } & Lokasi/pulau & Tahun \\
\hline 1 & Nieuw (Warwijk) & Ambon & 1599 \\
\hline
\end{tabular}

\section{Tabel 4: Sebaran benteng yang dibangun pada fase II}

\begin{tabular}{|c|l|l|l|}
\hline No. & \multicolumn{1}{|c|}{ Nama benteng } & Lokasi/pulau & Tahun \\
\hline 1 & Orange & Ternate & 1607 \\
\hline 2 & Nassau & Banda & 1609 \\
\hline 3 & Belgica & Banda & 1611 \\
\hline 4 & Kastel Revengie & Banda & 1616 \\
\hline 5 & Hollandia & Banda & 1624 \\
\hline 6 & Danek of de Morgenter & Ambon & 1626 \\
\hline 7 & Fort Nieuw Zeelandia & Haruku & 1626 \\
\hline 8 & Oma & Haruku & 1627 \\
\hline 9 & Hardewyk & Seram & $1628-1631$ \\
\hline 10 & Rotterdam & Ambon & 1633 \\
\hline 11 & Ama Ika & Saparua & - \\
\hline 12 & Ouw & Saparua & - \\
\hline 13 & Wawane & Ambon & - \\
\hline 14 & Kapahaha & Ambon & - \\
\hline 15 & Blokhuis Harlem & Ambon & 1655 \\
\hline 16 & Fort Hoorn & Haruku & 1656 \\
\hline 17 & Fort Wantrow & Seram & 1657 \\
\hline 18 & Fort Dellen Haven & Kisar & 1665 \\
\hline 19 & V.D. Capellen & Ambon & 1680 \\
\hline 20 & Defensie & Buru & 1689 \\
\hline 21 & Duurstede & Saparua & $1690-1691$ \\
\hline 22 & Hollandia & Saparua & 1691 \\
\hline & & & \\
\hline
\end{tabular}

\section{Tabel 5: Sebaran benteng yang dibangun pada fase III}

\begin{tabular}{|c|l|l|l|}
\hline No. & \multicolumn{1}{|c|}{ Nama benteng } & \multicolumn{1}{|c|}{ Lokasi/pulau } & Tahun \\
\hline 1 & Folen Haven & Moa & 1712 \\
\hline 2 & Den Haan & Sewaru & 1734 \\
\hline 3 & Beverwyk & Saparua/Nusalaut & 1845 \\
\hline
\end{tabular}

Berdasarkan tabel tersebut, memperlihatkan bahwa pada periode awal kedatangan Belanda di Maluku hanya satu benteng yang dibangun yaitu Nieuw Victoria di Ambon. Benteng ini dibangun sebagai benteng pertahanan pertama di Maluku dan memutuskan daerah Ambon sebagai pusat perdagangan dan pemerintahan. Periode berikutnya, dibangun 22 benteng pertahanan yang tersebar di Kepulauan Maluku.

\section{Sistem Pertahanan di Maluku abad XVII - Abad XIX}

Berdasarkan pengamatan terhadap keletakan benteng yang ada di Maluku yaitu benteng yang ditempatkan di daerah pesisir dan daerah perbukitan memberikan asumsi bahwa benteng yang dibangun di daerah pesisir berkaitan dengan strategi dan taktik perang maritim. Profil wilayah Maluku yang merupakan wilayah Kepulauan sangat tepat dengan strategi ini. Benteng-benteng yang dibangun sebelum abad XVII oleh Portugis dan Inggris, diambil alih oleh Belanda untuk memperkuat sistem pertahanan mereka di Maluku. Ternate, Bacan, Jailolo (Halmahera) dan Kepulauan Banda merupakan daerah yang diperkuat oleh Portugis dengan benteng-benteng pertahanan, akan tetapi dengan berbagai pertimbangan dan perubahan politik di Eropa maka benteng-benteng tersebut ditinggalkan. Hal ini, menjadi keuntungan tersendiri bagi Belanda dan tidak perlu mengeluarkan biaya untuk memperkuat daerah-daerah penting di Kepulauan Maluku. 
Daerah-daerah penting pada saat itu diantaranya, Ternate sebagai sentra produksi dan pusat pengumpul cengkeh untuk wilayah sekitarnya, demikian halnya dengan Ambon dan pulau-pulau di sekitarnya. Sementara itu, Kepulauan Banda merupakan sentra produksi dan pusat pengumpul komoditi pala untuk wilayah sekitarnya. Dengan demikian, ketiga daerah ini diperkuat dengan sistem pertahanan yang lebih kuat, pola sebaran benteng di wilayah ini memperlihatkan hal tersebut. Ternate diperkuat dengan tiga benteng yang kokoh dan ditempatkan di daerah pesisir. Sementara Pulau Ambon dan wilayah sekitarnya lebih banyak lagi yaitu 15 benteng, 7 diantaranya ditempatkan di Ambon sebagai pusat pemerintahan Belanda di Maluku, 5 benteng di Pulau Saparua dan 3 benteng di Pulau Haruku. Sistem pertahanan yang kuat di ketiga pulau ini disebabkan karena ketiga daerah ini memberikan perlawanan yang kuat pula terhadap kedudukan Belanda di Maluku. Sementara di Kepulauan Banda terdapat 5 benteng pertahanan, satu diantaranya dibangun oleh Inggris tetapi kemudian ditinggalkan. Sistem pertahanan yang dibangun oleh Belanda di daerah ini tidak hanya untuk mengantisipasi perlawanan dari masyarakat Banda. Tetapi juga, menghadapi persaingan dagang dengan Inggris sehingga mengharuskan Belanda membangun pertahanan yang kuat di daerah ini. Perebutan penguasaan atas daerah ini begitu sengit terjadi sehingga diatara kedua negara tersebut silih berganti menguasai Banda. Penaklukan dibawah kepemimpinan Jan Pieterszoon Coen pada tahun 1621 atas Kepulauan Banda adalah peristiwa besar bagi daerah ini. Dan pada tahun 1810, tentara Inggris berhasil mengambil alih namun tidak lama kemudian pada tahun 1824 diserahkan kembali kepada Belanda karena adanya perubahan politik di Eropa pada saat itu.

Secara kronologis sistem pertahanan pada abad XVI didominasi oleh Portugis dengan membangun 3 benteng pertahanan diantaranya pada tahun 1512, 1532 dan 1640 di Ternate. Sementara Belanda memutuskan untuk mulai membangun sistem pertahanannya di Ambon dengan membangun benteng pada tahun 1599. Sistem pertahanan yang kuat dibangun oleh Portugis sebagai langkah antisipasi terhadap serangan pesaingnya sesama bangsa Eropa di Ternate. Sementara itu, persaingan antara Ternate yang didukung oleh Portugis dan Tidore yang didukung oleh Spayol memberi andil cukup besar dalam sistem pertahanan yang dibangun di wilayah ini. Di pihak lain, Belanda yang memperkuat pertahanannya di bagian selatan terutama Ambon dan Banda berebut pengaruh dengan Inggris. Akan tetapi, beberapa perubahan politik antara Belanda dan Inggris menyebabkan kedua negara ini mengadakan perjanjian rahasia untuk memaksa Portugis dan Spayol hengkang dari wilayah ini. Perjanjian pada tanggal 17 Juli 1619 itu berisi tentang pembagian pembiayaan untuk "proyek" tersebut, East India Company (Inggris) menyediakan sepertiga dari tenaga manusia, biaya dan kapal sedangkan Vereenigde Oost Indische (Belanda) menyediakan dua pertiga sisanya (Hanna, 1983:49).

Pada abad XVII, sistem pertahanan didominasi oleh Belanda dengan membangun 22 benteng pertahanan. Daerah-daerah yang diperkuat oleh Belanda pada saat itu yaitu pulau Ambon sebagai pusat aktifitas perdagangan dan pemerintahan dengan membangun 6 benteng pertahanan. Sebagian besar dari benteng tersebut ditempatkan di Hitu dengan membangun 4 kubu pertahanan untuk meredam perlawanan rakyat Hitu. Dan di Saparua, dibangun 4 kubu pertahanan diantaranya, benteng Duurstede pada tahun 1690/1691, Hollandia pada tahun 1690, dan benteng Ama Iha serta Ouw. Salah satu benteng tersebut menjadi kubu pertahanan dalam perang besar Belanda meredam perlawanan rakyat Maluku dibawah kepemimpinan Kapitan Pattimura. Demikian pula dengan pulau di sekitarnya yaitu pulau Haruku dibangun 3 benteng pertahanan. Daerah lain yang tidak kalah strategisnya yaitu Kepulauan Banda dibangun 4 benteng pertahanan (salah satunya dibangun oleh Inggris). Pulau ini dianggap sangat penting mengingat daerah ini sebagai penghasil pala terbesar di Maluku. Selain itu, bentengbenteng yang dibangun di pulau-pulau lain dimaksudkan sebagai pos pengawas bagi perkebunan-perkebunan Belanda. Diantaranya, benteng Hardewyk pada tahun 1628-1631 dan Fort Wantrow pada tahun 1657 di Seram dan benteng Fort Dellen Haven pada tahun 1665 di pulau Kisar. Contoh lain yaitu di Bacan, Belanda mengembangkan perkebunan kopi dan menempatkan benteng Bernaveld. 
Pada periode akhir yaitu abad XVIII-XIX, Belanda hanya membangun 3 kubu pertahanan. Hal ini tidak berarti kedudukan Belanda mulai melemah akan tetapi situasi yang semakin kondusif sehingga Belanda merasa tidak perlu menambah kubu pertahanannya. Setelah perang Pattimura pada tahun 1817, tidak ada lagi perlawanan besar dari masyarakat lokal. Benteng-benteng yang dibangun pada masa ini yaitu Follen Haven pada tahun 1712 di Moa, Den Haan pada tahun 1734 di Serwaru, dan Beverwyk pada tahun 1845 di Saparua/ Nusalaut.

Sejarah penguasaan VOC dan pemerintah Belanda atas berbagai wilayah di Maluku dibagi dalam tiga fase yaitu:

1. Pada awal kedatangannya VOC pada saat itu hanya menempatkan wakil-wakil perdagangannya diberbagai wilayah di Maluku. Hal ini karena pada awalnya mereka datang dengan tujuan perdagangan.

2. Fase selanjutnya dengan tujuan memonopoli perdagangan rempah-rempah dan berbagai komoditi lainnya. Mereka kemudian membangun benteng-benteng pertahanan untuk meredam perlawanan penguasa-penguasa lokal dan memenangkan persaingan dengan pedagang-pedagang asing lainnya. Pada masa ini, mereka mengatur berbagai urusan perdagangan dan hal-hal lainnya di dalam benteng (kehidupan intra muros).

3. Dan fase terakhir berlangsung setelah keadaan mulai kondusif dan perlawanan-perlawanan rakyat Maluku berhasil diredam. Fase ini juga ditandai dengan pembangunan berbagai fasilitas di luar benteng oleh Pemerintah Belanda. Dengan adanya berbagai fasilitas ini maka kehidupan kota kolonial telah dimulai. Kota-kota yang ada di Maluku seperti Ambon, Banda, Ternate, dan Tidore bahkan kota-kota kecil memperlihatkan hal ini. Tidak hanya itu, perusahaan-perusahaan swasta bahkan diberikan hak oleh Pemerintah Belanda untuk mengelola perkebunan-perkebunannya. Faktor lain yang menyebabkan keleluasaan Pemerintah Belanda di nusantara pada umumnya adalah dengan adanya perjanjian antara negara kolonial di Eropa yang memberikan "jatah" penguasaan di wilayah ini.
Dengan demikian, berdasarkan pengamatan terhadap sistem pertahanan di Maluku pada abad XVII-XIX dapat dikemukakan beberapa asumsi, diantaranya:

1. Berdasarkan keletakannya, benteng-benteng di Maluku ditempatkan di daerah pesisir/tepi pantai dan daerah perbukitan. Hal ini, berkaitan dengan strategi dan taktik perang maritim dengan melihat kondisi wilayah Maluku berupa kepulauan. Sementara benteng-benteng yang dibangun di daerah perbukitan merupakan kubu pertahanan terhadap perlawanan-perlawanan dari penguasa lokal.

2. Daerah-daerah strategis di Maluku seperti Ternate, Ambon, Saparua dan Kepulauan Banda dibangun sistem pertahanan yang kuat. Ternate sebagai daerah penghasil cengkeh pada awalnya diperkuat oleh Portugis yang merupakan negara pertama yang mengeksplorasi daerah ini dan dilanjutkan oleh Belanda. Sedang Ambon dan sekitarnya diperkuat karena merupakan pusat aktifitas Belanda di Maluku, daerah Saparua dan Haruku diperkuat karena adanya perlawanan yang kuat dari masyarakat dikedua daerah tersebut. Sementara Kepulauan Banda merupakan penghasil pala terbesar di Maluku.

3. Perebutan pengaruh diantara negara-negara kolonial menjadi salah satu faktor (selain adanya perlawanan penguasa-penguasa lokal) dibangunnya sistem pertahanan yang kuat di Maluku. Ternate menjadi ajang perebutan antara Portugis dan Spanyol, sementara Kepulauan Banda diperebutkan oleh Belanda dan Inggris. Demikian halnya dengan Ambon menjadi rebutan diantara negaranegara kolonial, namun berhasil dikuasai oleh Belanda dengan menduduki benteng pertahanan yang kuat, peristiwa ini diabadikan dengan memberi nama benteng tersebut Nieuw Victoria.

Disadari bahwa sumber-sumber yang digunakan dalam penulisan ini dirasa masih kurang, diantaranya untuk mengungkapkan sistem pertahanan diperlukan sumber utama yang tidak kalah 
pentingnya yaitu peta-peta yang dibuat pada masa tersebut. Oleh karena itu, diperlukan pengamatan yang lebih mendalam terhadap peta-peta tersebut untuk mengungkapkan sistem pertahanan di Maluku.

\section{DAFTAR PUSTAKA}

Abbas, 2005,

Sistem Pertahanan di Batavia Abad VII-XVIII, Dalam Pertemuan Ilmiah Arkeologi VII. Jakarta: Proyek Penelitian Arkeologi Jakarta, 1998-1999.

Hanna, W.A, 1983,

Kepulauan Banda Kolonialisasi dan Akibatnya di Kepulauan Pala, Jakarta: PT. Gramedia.

Kustoro L.P. dan Rumere Y, 2004

Rempah Timur dalam Kuliner Barat: Upaya Penyediaan dan Penggunaannya, Dalam Berkala Arkeologi Sangkhakala, Medan: Balai Arkeologi Medan.

Rijoly, Frans, 1989

Guide Book, Indonesia-English Edition, Ambon: Musium Siwalima Ambon, Proyek Pembinaan Permusiuman Maluku.

Suantika, I Wayan, 2005,

Peran dan Fungsi Benteng Peninggalan Masa Kolonial bagi Pembangunan Daerah Maluku", Dalam Evaluasi Hasil Penelitian Arkeologi (EHPA) Yogyakarta 2005, Belum Terbit

Triwuryani, 1995

Alokasi Situs-situs Arkeologi di Kawasan Das Way Sekampung, makalah seminar Manusia dalam Ruang Studi Kawasan Arkeologi, Yogyakarta, 15 - 16 Maret. 